\title{
Skrining Virtual dan Elusidasi Moda Ikatan Senyawa dalam Bawang Putih (Allium sativum L.) sebagai Penghambat Reseptor Advanced Glycation End Products
}

\section{(Screening Virtual and Binding Mode Elucidation of Compounds in Garlic (Allium sativum L.) as an Inhibitor Advanced Glycation End Products Receptor )}

\author{
ESTI MULATSARI*, ESTI MUMPUNI, IKHSAN RAMADHAN
}

\author{
Fakultas Farmasi Universitas Pancasila, Srengseng Sawah, Jagakarsa, Jakarta Selatan \\ *Penulis korespondensi, Hp : 085729086842 \\ e-mail: estimulatsari@univpancasila.ac.id
}

Diterima 22 Juli 2019, Disetujui 26 September 2019

\begin{abstract}
Abstrak: Diabetes memiliki dampak jangka panjang seperti aterosklerosis, nefropati, dan retinopati yang disebabkan oleh pembentukan Advanced Glycation End Products (AGEs). Penelitian secara in vitro pada ekstrak bawang putih (Allium sativum L.) terhadap aktivitas penghambatan pembentukan AGEs telah banyak dilakukan, namun belum diketahui mekanisme penghambatan dan senyawa apa yang berperan aktif dalam aktivitas penghambatan tersebut. Penelitian ini bertujuan untuk melakukan skrining virtual senyawa - senyawa dalam bawang putih (Allium sativum L.) yang aktif menghambat reseptor Advanced Glycation Endproduct sehingga senyawa aktif bisa dipertimbangkan sebagai kandidat senyawa obat. Metode yang digunakan adalah molecular docking dengan software PLANTS, YASARA, MarvinSketch, dan visualisasi ikatan senyawa uji pada asam amino reseptor menggunakan PyMOL, piridoksamin dan aminoguanidin digunakan sebagai kontrol positif inhibitor AGEs. Hasil docking 24 senyawa uji diperoleh tujuh senyawa yang aktif menghambat reseptor 3B75.pdb dan lima senyawa aktif menghambat reseptor 3O3U.pdb. Kandidat senyawa obat terdiri dari senyawa organosulfur, fenol dan flavonoid. Senyawa Y-glutamil-sistein, E-ajoene, No-(1-Deoksi-Dfructosa-1YL)-L-Arginin, Kaempferol-3-o- $\beta$-D-glukopiranosa, Iso-rhamnetin-3-o- $\beta$-D-glukopiranosa merupakan senyawa - senyawa dalam bawang putih yang memiliki kemampuan menghambat baik reseptor $3 \mathrm{~B} 75$ maupun $3 \mathrm{O} 3 \mathrm{U}$ dengan aktivitas yang lebih baik dari piridoksamin dan aminoguanidin.
\end{abstract}

Kata kunci: Inhibitor, advanced glycation endproducts, diabetes, bawang putih (Allium sativum L.)

\begin{abstract}
Diabetic has long-term effects such as atherosclerosis, nephropathy, and retinopathy caused by the formation of Advanced Glycation End Products (AGEs). In vitro studies on garlic extract (Allium sativum L.) have been carried out on the inhibition activity of AGEs formation, but inhibitory mechanisms and which active compounds are involved in these activities are unknown. This study aims to do a virtual screening of garlic compounds (Allium sativum L.) on Advanced Glycation Endproduct receptors so that active compounds can be considered as candidates for drug compounds. The method used is molecular docking with PLANTS, YASARA, MarvinSketch software, and visualization of test compound bonds on receptor amino acids using PyMOL. Pyridoxamine and Aminoguanidine as a positive control of AGEs inhibitors. The docking results of 24 test compounds obtained seven compounds that active in inhibiting 3B75 receptor and five compounds in 3O3U receptor. Candidates for drug compounds consist of organosulfur, phenols and flavonoids. V-glutamyl-cysteine, E-ajoene, $\mathrm{N} \alpha$ - (1-Deoxy-Dfructose-1-YL) -L-Arginine, Kaempferol-3-o- $\beta$-D-glucopyranose, and Iso-rhamnetin$3-0-\beta$-D-glucopyranose are compounds in garlic which have an ability to inhibit $3 \mathrm{~B} 75$ and $3 \mathrm{O} 3 \mathrm{U}$ receptors and predicted have better activity than pyridoxamine and aminoguanidine.
\end{abstract}

Keywords: Inhibitor, advanced glycation endproducts, diabetic, garlic (Allium sativum L.) 


\section{PENDAHULUAN}

HIPERGLIKEMIA dalam jangka waktu lama menyebabkan terbentuknya AGEs yang mana akan berujung pada akumulasi di berbagai jaringan sehingga dapat meningkatkan stress oksidatif. Hal ini akan memicu sistem pertahanan tubuh untuk mengeliminasi produk tersebut dengan menggunakan makrofag dengan reseptor advanced glycosylation, makrofag akan mengsekresikan TNF- $\alpha$ dan ILE-1 (pro-inflamatory cytokine) yang dapat menyebabkan inflamasi lokal pada pembuluh darah, hal inilah yang mempercepat terjadinya aterosklerosis, nefropati, neuropati, retinopati serta menjadi awal mula berbagai komplikasi pada penderita diabetes ${ }^{(1)}$.

Penghambatan pembentukan AGEs pada penyakit diabetes dapat membatasi kerusakan jaringan, memperlambat progresivitas penyakit dan meningkatkan kualitas hidup, untuk itu diperlukan obat yang dapat mencegah pembentukan senyawa AGEs (Inhibitor Advance Glycation End Product) baik obat modern maupun obat tradisional yang berasal dari tumbuh-tumbuhan. Pemanfaatan tanaman obat di Indonesia pada saat ini semakin meningkat, dan Indonesia merupakan negara tropis yang memiliki berbagai jenis tanaman obat. Bawang putih (Allium sativum L.) adalah bahan alami yang sering digunakan masyarakat untuk pengobatan, seperti mengurangi kolesterol dan menjaga kadar glukosa darah $^{(2)}$. Berbagai penelitian telah dilakukan mengenai aktivitas inhibisi terhadap reseptor advance glycation end product dari berbagai senyawa alamiah, antara lain ekstrak bawang putih (Allium sativum L.) yang terbukti dapat menghambat pembentukan AGEs secara in vitro dengan S-metil-sistein (SMC) sebagai kandungan terbanyak ${ }^{(2,3)}$. Namun belum diketahui senyawa apa saja dari kandungan bawang putih (Allium sativum L.) yang memiliki efek penghambatan terhadap pembentukan AGEs serta belum ada penjelasan pasti tentang mekanisme penghambatannya terhadap reseptor AGEs. RAGE (Receptor Advanced Glycation End product) adalah reseptor transmembran (G-protein-coupled receptor), merupakan protein permukaan sel multifungsi dari sistem kekebalan tubuh manusia yang dianggap memiliki peran penting pada diabetes, peradangan kronis, penyakit neurodegeneratif dan kanker. Struktur RAGE terbagi menjadi lima domain, terdiri dari sitoplasmik domain yang bertanggungjawab pada transduksi sinyal, transmembrane domain, variable domain tempat mengikat ligan, dan dua domain konstan ${ }^{(4)}$. RAGE diketahui terlibat dalam berbagai keadaan patologis terkait peradangan. Aktivasi RAGE dan transduksi sinyal yang dihasilkan tergantung pada jenis dan konsentrasi ligan yang berikatan pada reseptor. RAGE dapat berinteraksi dengan berbagai ligand terutama advanced glycation end products (AGEs), amfoterin (HMGB1), keluarga protein $\mathrm{S} 10^{(5)}$.

Piridoksamin dilaporkan memiliki aktivitas penghambatan terhadap pembentukan AGEs, menghambat modifikasi kimiawi protein dan mengikat senyawa reaktif yang berasal dari karbohidrat dan lemak ${ }^{(6)}$. Oleh karena itu, pada penelitian ini digunakan piridoksamin sebagai kontrol positif untuk dibandingkan dengan senyawa uji. Skrining virtual dilakukan secara in silico dengan melakukan docking senyawa uji pada RAGE. Software yang digunakan antara lain ChemSketch, YASARA dan PyMol, serta PLANTS sebagai operator docking ligan-reseptor. Score docking dinyatakan dalam bentuk ChemPLP yang menentukan afinitas interaksi ligan-reseptor ${ }^{(7)}$. Metode ini telah banyak digunakan untuk uji aktivitas biologis suatu senyawa seperti uji aktivitas senyawa sebagai antibakteri, antioksidan, dan antikanker ${ }^{(8-9)}$. Dari penelitian ini diharapkan dapat diketahui senyawa dalam bawang putih (Allium sativum L.) yang dapat dijadikan kandidat senyawa obat penghambat pembentukan AGEs.

\section{BAHAN DAN METODE}

BAHAN. Struktur virtual 2D senyawa dalam bawang putih (Allium sativum L.) : Gamma-glutamil-sistein, 3-(Allylsulphinyl)-L-alanine, Diallyl thiosulfinate, Diallil disulfida (DADS), Diallil sulfida (DAS), Diallil trisulfida (DATS), Metalil sulfida, Dipropil sulfida, Dipropil disulfida, Allil merkaptan, Allil metil sulfida, E-ajoene, 2-vinil-(4H)-1,3-dithiin, Selenometionin, S-propilsistein (SPC), S-etil-sistein (SEC), Smetilsistein (SMC), Selenosistein, Se-(metil)selenosistein, kempferol-3-O- $\beta$-Dglukopiranosa, iso-rhamnetin-3O- $\beta$-Dglukopiranosa, N $\alpha$-(1-deoxy-Dfructose-1-yl)L-arginin, S-alil sistein (SAC), S-allilmerkaptosistein (SAMC) [10]. Reseptor advance glycation end product (RAGE) dengan kode pdb : 3B75, 4IW2, 3O3U , 2MOV [11]. Struktur 2D piridoksamin dan aminoguanidin.

Alat. Software : Protein-Ligand ANT System (PLANTS) yang dapat diunduh di http://www.tcd.unikonstanz.de/index.php. YASARA yang dapat diunduh di : http://www.yasara.org/viewdl.htm, ChemSketch yang dapat diunduh di: http://www.chemaxon.com/ marvin/download-user.html, PyMOL yang dapat diunduh di: https://pymol.org Hardware : Laptop ASUS A455L Intel Core i3-4005U 1,7GHz, NVIDIA 930M, 64-bit Operating System.

METODE. Secara umum metode penelitian yang digunakan mengacu pada prosedur molecular 
docking dengan PLANTS oleh Korb O, et al, 2006 dan Purnomo, H, 2011 ${ }^{(12,13)}$.

Preparasi Reseptor. Struktur komplek protein dalam format (.pdb) didapatkan dari Protein Data Bank (PDB) di-download dari situs http://www.rscb. org/ dipreparasi kembali dengan program YASARA dari prosedur ini dapat diperoleh tiga file yaitu protein. mol2, ref_ligand.mol2 dan ligand.mol2.

Preparasi Ligan Protein, Ligan Pembanding, dan Ligan Uji. Preparasi ligan protein, ligan senyawa pembanding, ligan senyawa uji dengan MarvinSketch pada $\mathrm{pH} 7,4$, Ligan disimpan sebagai ligand_2D. mrv., Pilih Conformational search lalu simpan hasil perncarian konformasi sebagai ligan dan tipe file .mol2., Prosedur diatas dilakukan untuk setiap satu ligan.

Penentuan nilai RMSD. Native ligan yang sudah dipreparasi, lalu dioptimasi dengan struktur kristal protein menggunakan program PLANTS hingga didapat score. Dipilih score terbaik lalu disimpan dalam bentuk file mol 2. Dihitung besarnya nilai RMSD pose hasil optimasi dengan referensi hasil eksperimen atau struktur kristal protein dengan program YASARA.

Docking Ligan Pembanding Terhadap Reseptor. Dari tiga file yang diperoleh dari prosedur preparasi protein kemudian dilakukan docking dengan menggunakan program PLANTS,dengan mengetik command pada lembar kerja cmd, program PLANTS akan membaca protokol plantsconfig yang telah di set sebelumnya hingga diperoleh besarnya nilai best score dari ligan senyawa pembanding yang nantinya akan dibandingkan dengan nilai best score dari ligan senyawa uji.

Docking Ligan Uji Terhadap Reseptor. Pada prosedur ini dilakukan docking antara masing-masing ligan senyawa uji menggunakan program PLANTS. Hasil docking diperoleh nilai best score ligan senyawa uji, nilai inilah yang akan dibandingkan dengan best score ligan senyawa pembanding.

Visualisasi Interaksi Ligan dan Reseptor. Langkah selanjutnya adalah membuat file hasil docking dari masing-masing ligan senyawa uji dengan program YASARA (tipe file.pdb). File hasil docking inilah yang akan divisualisasi dan diinterpretasi untuk diketahui interaksi-interaksi yang terjadi menggunakan aplikasi PyMOL.

\section{HASIL DAN PEMBAHASAN}

Reseptor yang digunakan dalam metode molecular docking merupakan struktur yang diunduh dari Protein Data Bank (PBD) dalam bentuk kristal yang sudah disesuaikan dengan struktur asli dari reseptor pada tubuh manusia serta memiliki nilai resolusi yang baik. Nilai resolusi atau biasa disebut dengan Root Mean Square Deviation (RMSD) didapatkan dengan validasi reseptor menggunakan metode molecular docking, dipilih reseptor yang menghasilkan nilai RMSD kurang dari atau sama dengan $2 \AA$. (Tabel 1). Dari empat jenis reseptor advanced glycation end products yang divalidasi, diperoleh dua reseptor yang memenuhi persyaratan yaitu dengan kode PDB : 3B75 dan 3O3U, reseptor ini memenuhi syarat RMSD kurang dari atau sama dengan $2 \AA$. Validasi protokol molecular docking dengan RMSD kurang dari $2 \AA$ bertujuan agar posisi ligand yang berikatan pada sisi aktif protein (active site) pergeserannya tidak terlalu jauh karena konversi dari $2 \AA$ sama dengan $0,2 \mathrm{~nm}$ sesuai dengan kisaran ukuran diameter suatu atom yaitu sekitar $0,1 \mathrm{~nm}$. Superposisi dari ligand referensi dengan ligand hasil docking ditunjukkan oleh Gambar 1.
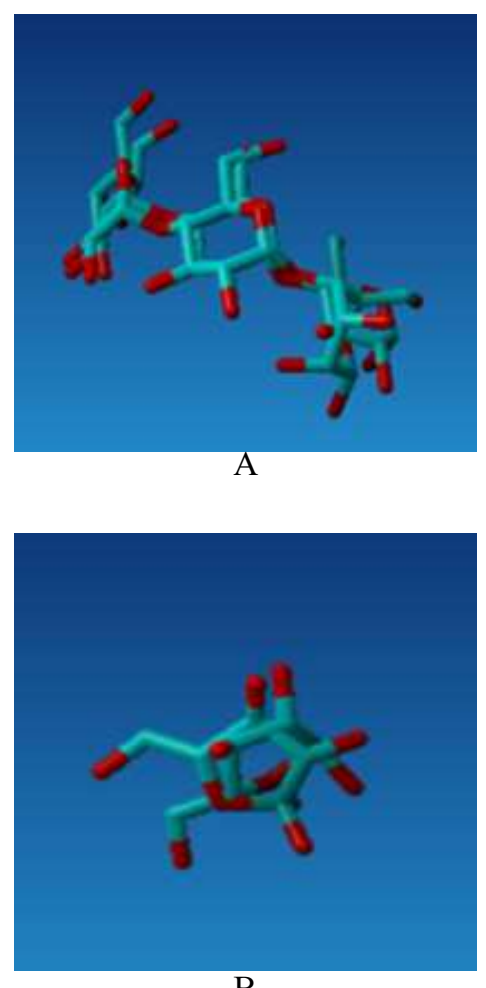

Gambar 1. Allignment posisi ligand referensi dengan ligand hasil docking A) Hasil RMSD reseptor 303U B) Hasil RMSD reseptor 3B75

Docking dilakukan pada sisi aktif dari reseptor dengan senyawa pembanding dan senyawa uji. Score ChemPLP yang diperoleh dari native ligand, senyawa pembanding dan senyawa uji pada sisi aktif reseptor dibandingkan satu sama lain. Nilai ChemPLP merepresentasikan energi bebas Gibbs, dimana semakin kecil nilai $\Delta \mathrm{G}$ interaksi ligand dengan 
reseptor akan semakin stabil ${ }^{(14,15)}$. Score ChemPLP pada piridoksamin dan aminoguanidin menunjukan korelasi dengan pengujian secara in vitro. Aktivitas piridoksamin dalam penghambatan pembentukan
AGEs secara in vitro lebih baik dibandingkan dengan aminoguanidin, sesuai dengan score ChemPLP piridoksamin yang lebih negatif (Tabel 2).

Tabel 1. Nilai RMSD Reseptor Advanced Glycation Endproduct.

\begin{tabular}{clcc}
\hline No. & \multicolumn{1}{c}{ Reseptor } & Kode & $\begin{array}{c}\text { RMSD } \\
(\AA)\end{array}$ \\
\hline 1 & Crystal Structure of Glycated Human Haemoglobin & $3 \mathrm{~B} 75$ & 2,0465 \\
2 & $\begin{array}{l}\text { Human Serum Albumin-glucose complex } \\
\text { Crystal Structure of Human Receptor for Advanced Glycation End products }\end{array}$ & $4 \mathrm{IW} 2$ & 2,8766 \\
$\begin{array}{l}\text { (RAGE) } \\
\text { Receptor for Advanced Glycation End Products (RAGE) Specifically } \\
\text { Recognizes Methylglyoxal derived AGEs, }\end{array}$ & $2 \mathrm{MOV}$ & 1,3517 \\
\hline
\end{tabular}

Tabel 2. Score ChemPLP senyawa pembanding.

\begin{tabular}{ccccc}
\hline \multirow{3}{*}{ In Silico } & Reseptor & Native ligand & $\begin{array}{c}\text { Score (ChemPLP) } \\
\text { Piridoksamin }\end{array}$ & Aminoguanidin \\
\cline { 2 - 5 } & $3 \mathrm{~B} 75$ & $-52,8628$ & $-55,6736$ & $-43,0837$ \\
& 3O3U & $-100,4580$ & $-72,0426$ & $-50,5360$ \\
\hline \multicolumn{2}{c}{ Inhibisi pembentukan AGEs secara in vitro dengan } \\
\multicolumn{2}{c}{ konsentrasi 10 mM (21) } \\
\hline
\end{tabular}

Hasil docking senyawa uji yaitu senyawa-senyawa dalam bawang putih ditunjukkan oleh Tabel 3. Hasil docking senyawa-senyawa di dalam bawang putih pada reseptor 3B75 menunjukan kandidat senyawa aktif yang memiliki aktivitas yang lebih baik atau setara dengan pembandingnya (piridoksamin) sebanyak tujuh senyawa dari dua puluh empat senyawa uji. Beberapa dari senyawa tersebut merupakan turunan alami dari senyawa inti pada bawang putih (Allium sativum L.) yaitu seyawa organosulfur dan flavonoid. Senyawa dengan nilai ChemPLP terbaik (paling negatif) ialah senyawa No-(1-Deoksi-D-fructosa-1-YL)-L-Arginin. Senyawa ini potensial dikembangkan untuk kandidat obat sebagai penghambat reseptor 3B75. Reseptor 3B75.pdb merupakan struktur kristal hemoglobin manusia yang terglikasi, dimana terdapat ikatan antara glukosa dengan sisi aktif hemoglobin, yang pada akhirnya produk hasil glikasi ini akan menjadi proses awal dari terbentuknya AGEs. Inhibisi pada reseptorreseptor tersebut akan mencegah pembentukan AGEs di dalam tubuh. Pada reseptor 3O3U.pdb diperoleh lima senyawa yang memiliki score ChemPLP lebih negatif dari senyawa pembanding dengan senyawa Iso-rhamnetin-3-o- $\beta$-D-glukopiranosa yang memiliki nilai paling negatif. Reseptor 3O3U.pdb adalah struktur kristal dari reseptor advanced glycation end products, dimana pada enzim ini terdapat interaksi antara reseptor dengan native ligand berupa protein yang terglikasi, interaksi keduanya dapat memicu timbulnya inflamasi di dalam tubuh. Dengan demikian inhibisi pada reseptor ini akan mencegah terjadinya inflamasi lokal pada jaringan sehingga mencegah terjadinya komplikasi akibat diabetes..

Dari hasil yang didapatkan, beberapa senyawa yang memiliki afinitas kuat terhadap reseptor diprediksi mempunyai aktivitas penghambatan pembentukan AGEs berdasarkan aktivitas senyawa pembanding. Senyawa $\mathrm{Y}$-glutamil-sistein, E-ajoene, $\mathrm{N} \alpha$-(1-DeoksiDfructosa-1-YL)-L-Arginin, Kaempferol-3-o- $\beta$-Dglukopiranosa, Iso-rhamnetin-3-o- $\beta$-D-glukopiranosa merupakan senyawa - senyawa dalam bawang putih yang memiliki kemampuan menghambat baik reseptor 3B75 maupun 3O3U. Senyawa Ekstrak bawang putih telah dibuktikan ativitas penghambatan pembentukan AGEs pada penelitian sebelumnya ${ }^{(2)}$.

Interaksi senyawa - senyawa aktif dengan asam amino pada bindingsite reseptor ditunjukkan pada Gambar 2. Gambar 2 menunjukan konformasi ligand, posisi ligand dalam bindingsite reseptor dan asam amino - asam amino yang berinteraksi. Salah satu interaksi yang terjadi antara ligand dan asam amino ialah terbentuknya ikatan hidrogen ikatan tersebut terbentuk pada jarak - jarak tertentu sebagaimana ditunjukkan pada Tabel 4. Dari hasil visualisasi, 
diperoleh asam amino yang berperan penting terhadap afinitas senyawa uji pada reseptor 3B75, yaitu : ASP99, HIS-97, TYR-145, LYS-144, CYS-93. Asam amino yang berperan adalah asam aspartat (ASP), histidin (HIS), triosin (TYR), lisin (LYS), sistein (CYS). Letak ikatan senyawa uji pada asam amino di reseptor 3B75 kurang lebih sesuai dengan ikatan native ligand pada asam amino reseptor, yaitu pada ASP-99, HIS-97, TYR-145, THR-38 dan CYS-93. Sedangkan asam amino yang berperan penting terhadap afinitas senyawa uji pada reseptor $3 \mathrm{O} 3 \mathrm{U}$, yaitu : GLU-45,
GLU-44, GLU-111, GLU-153, ASP-14, ASP-65, ARG-66, ASN-12, TYR 341, TRP-62, TRP-340, LYS15, SER-337. Asam amino yang berperan adalah asam glutamat (GLU), asam aspartat (ASP), arginin (ARG), asparagin (ASN), triosin (TYR), triptofan (TRP), lisin (LYS),serin (SER ). Letak ikatan senyawa uji pada asam amino di reseptor 3B75 kurang lebih sesuai dengan ikatan native ligand pada asam amino reseptor, yaitu pada GLU-44, GLU111, GLU-153, ASP-14, ASP-65, ARG-66, TYR-155, TRP-62 sebagaimana ditunjukkan pada Gambar $3^{(16,17)}$.

Tabel 3. Score ChemPLP senyawa-senyawa dalam bawang putih.

\begin{tabular}{|c|c|c|c|}
\hline \multirow[b]{2}{*}{ No } & \multirow[b]{2}{*}{ Senyawa Uji } & \multicolumn{2}{|c|}{ Nilai ChemPLP } \\
\hline & & $\begin{array}{c}\text { Reseptor 3B75 } \\
\text { Pembanding (Piridoksamin) } \\
-55,6736 \\
\end{array}$ & $\begin{array}{c}\text { Reseptor 3O3U } \\
\text { Pembanding (Piridoksamin) - } \\
72,0426 \\
\end{array}$ \\
\hline 1 & ? -glutamil-sistein & $-63,2606$ & $-82,2877$ \\
\hline 2 & 3-(allilsulfinil)-1-alanin & $-54,9378$ & $-68,3679$ \\
\hline 3 & Diallyl thiosulfinate & $-40,8349$ & $-54,2105$ \\
\hline 4 & Diallil sulfida & $-47,2528$ & $-57,8295$ \\
\hline 5 & Diallil disulfida & $-48,9827$ & $-59,9141$ \\
\hline 6 & Diallil trisulfida & $-50,7523$ & $-63,4587$ \\
\hline 7 & Dipropil sulfida & $-46,6395$ & $-56,8507$ \\
\hline 8 & Dipropil disulfida & $-48,3996$ & $-59,4590$ \\
\hline 9 & Metalil sulfida & $-52,7606$ & $-63,4595$ \\
\hline 10 & Allil metil sulfida & $-41,1645$ & $-50,4572$ \\
\hline 11 & Allil merkaptan & $-37,8241$ & $-46,1420$ \\
\hline 12 & E-ajoene & $-59,1436$ & $-81,9154$ \\
\hline 13 & 2-vinil-(4h)-1,3-dithiin & $-47,6077$ & $-57,0295$ \\
\hline 14 & S-metil-sistein & $-51,4021$ & $-60,1852$ \\
\hline 15 & S-etil-sistein & $-53,6580$ & $-63,2132$ \\
\hline 16 & S-propilsistein & $-56,1459$ & $-67,9839$ \\
\hline 17 & S-alil sistein & $-55,4593$ & $-68,9643$ \\
\hline 18 & S-allilmerkaptosistein & $-58,7543$ & $-70,0091$ \\
\hline 19 & Selenosistein & $-47,2377$ & $-53,4695$ \\
\hline 20 & Selenometionin & $-42,7372$ & $-64,2301$ \\
\hline 21 & Se-(metil)selenosistein & $-50,9521$ & $-61,3888$ \\
\hline 22 & $\begin{array}{l}\text { Na-(1-Deoksi-Dfructosa-1-YL)- } \\
\text { L-Arginin }\end{array}$ & $-75,5167$ & $-98,1765$ \\
\hline 23 & Kempferol-3-o- $\beta$-Dglukopiranosa & $-65,7408$ & $-85,3187$ \\
\hline 24 & $\begin{array}{l}\text { Iso-rhamnetin-3-o- } \beta \text {-D- } \\
\text { glukopiranosa }\end{array}$ & $-71,1706$ & $-99,7423$ \\
\hline
\end{tabular}




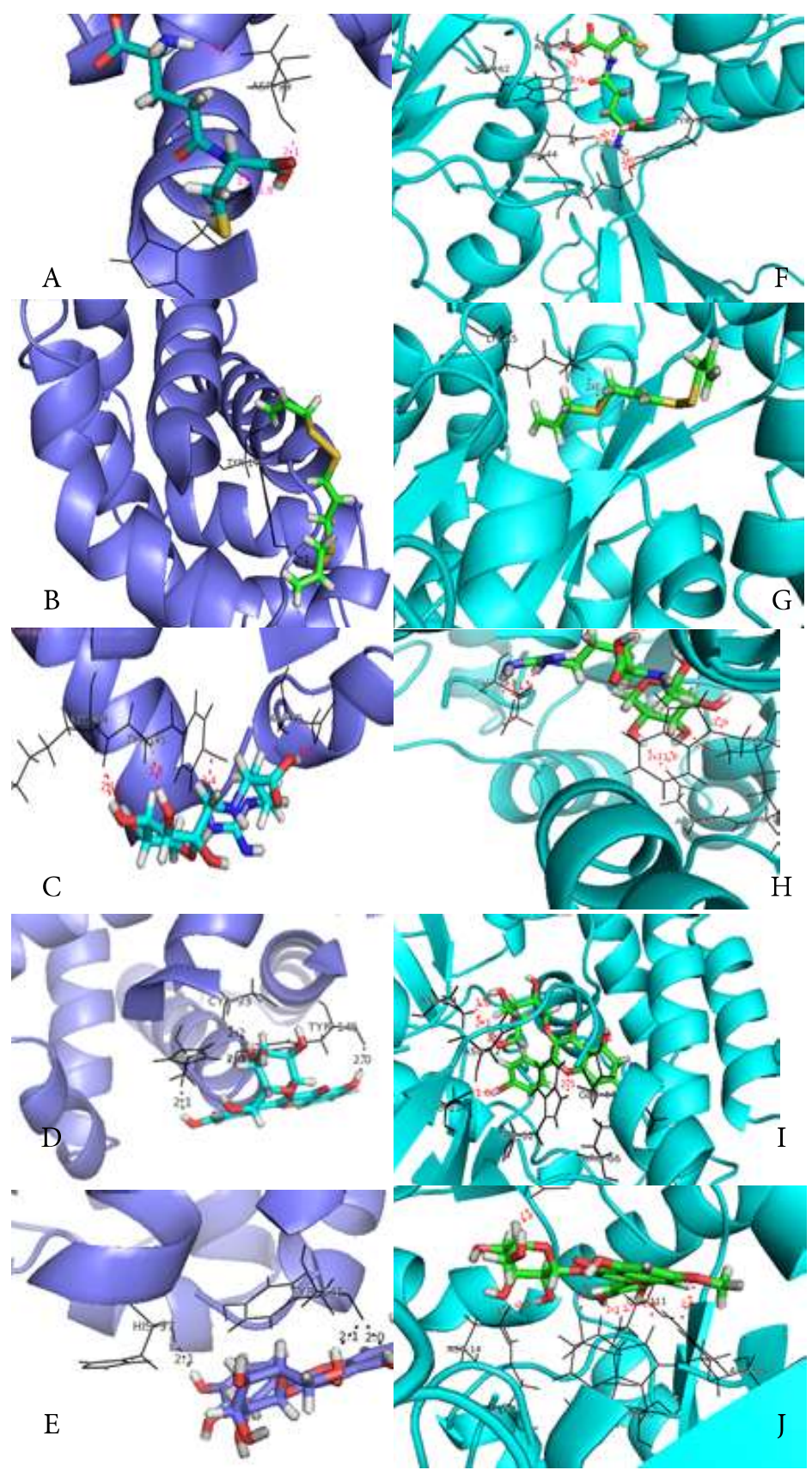

Gambar 2. Interaksi ligand dengan reseptor pada binding site reseptor A) Y-glutamil-sistein-3B75.pdb.B) E-ajo-

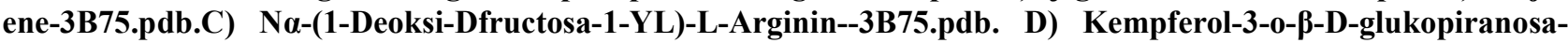

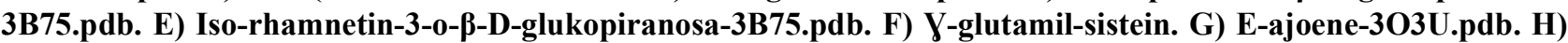

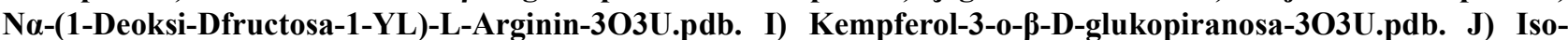
rhamnetin-3-o- $\beta$-D-glukopiranosa-303U.pdb.
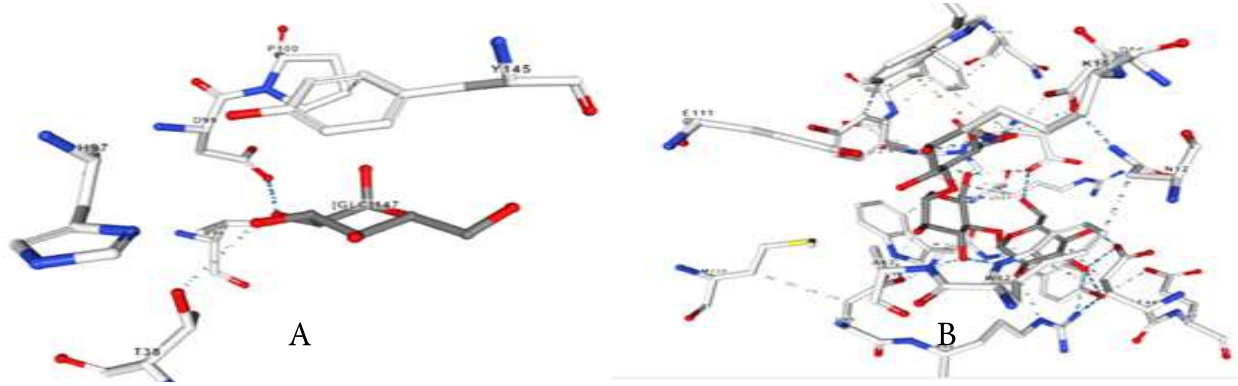

Gambar 3. A) ikatan native ligand pada asam amino reseptor 3B75 B) ikatan native ligand pada asam amino reseptor $303 \mathrm{U}$. 
Tabel 5. Asam Amino yang berinteraksi dengan ligand.

\begin{tabular}{|c|c|c|c|c|}
\hline \multirow{2}{*}{ Senyawa uji } & \multicolumn{2}{|c|}{$3 \mathrm{~B} 75$} & \multicolumn{2}{|c|}{$3 \mathrm{O} 3 \mathrm{U}$} \\
\hline & Asam amino & Panjang ikatan $(\AA)$ & Asam amino & Panjang ikatan $(\AA)$ \\
\hline ? -glutamil-sistein & $\begin{array}{l}\text { ASP-99 } \\
\text { HIS-97 }\end{array}$ & $\begin{array}{l}2,1 \\
1,7 \\
1,8\end{array}$ & $\begin{array}{c}\text { GLU-45 } \\
\text { GLU-44 } \\
\text { ASP-65 } \\
\text { TYR 341 } \\
\text { TRP-62 }\end{array}$ & $\begin{array}{l}2,1 \\
2,1 \\
2,0 \\
2,5 \\
2,1 \\
2,2 \\
\end{array}$ \\
\hline E-ajoen & TYR-145 & 2,3 & LYS-15 & 2,1 \\
\hline $\begin{array}{l}\text { Na-(1-Deoksi- } \\
\text { Dfructosa-1-YL)- } \\
\text { L-Arginin, }\end{array}$ & $\begin{array}{l}\text { ASP-99 } \\
\text { LYS-144 } \\
\text { TYR-145 }\end{array}$ & $\begin{array}{l}2,1 \\
2,1 \\
1,8 \\
2,4\end{array}$ & $\begin{array}{l}\text { GLU-153 } \\
\text { ASP-14 } \\
\text { ASP-65 } \\
\text { TRP-62 } \\
\text { LYS-15 }\end{array}$ & $\begin{array}{l}1,9 \\
2,1 \\
1,8 \\
2,1 \\
1,5 \\
2,1 \\
1,9 \\
2,2 \\
\end{array}$ \\
\hline $\begin{array}{l}\text { Kempferol-3-o- } \beta \text { - } \\
\text { D-glukopiranosa }\end{array}$ & $\begin{array}{c}\text { CYS-93 } \\
\text { HIS-97 } \\
\text { TYR-145 }\end{array}$ & $\begin{array}{l}2,2 \\
2,0 \\
2,1 \\
2,0\end{array}$ & $\begin{array}{c}\text { ARG-66 } \\
\text { GLU-44 } \\
\text { TRP-62 } \\
\text { ASN-12 } \\
\text { ASP-14 } \\
\text { GLU-111 }\end{array}$ & $\begin{array}{r}2,2 \\
2,1 \\
2,5 \\
2,3 \\
1,8 \\
2,1 \\
1,8\end{array}$ \\
\hline $\begin{array}{l}\text { Iso-rhamnetin-3- } \\
\text { o- } \beta \text {-D- } \\
\text { glukopiranosa }\end{array}$ & $\begin{array}{l}\text { HIS-97 } \\
\text { TYR-145 }\end{array}$ & $\begin{array}{l}2,1 \\
2,0 \\
2,1\end{array}$ & $\begin{array}{c}\text { GLU-153 } \\
\text { ARG-66 } \\
\text { GLU-44 } \\
\text { GLU-153 } \\
\text { TRP-62 } \\
\text { ASN-12 } \\
\text { ASP-14 } \\
\text { GLU-111 }\end{array}$ & $\begin{array}{l}1,8 \\
2,6 \\
2,1 \\
1,8 \\
2,4 \\
1,7 \\
2,1 \\
1,7 \\
2,1\end{array}$ \\
\hline
\end{tabular}

\section{SIMPULAN}

Hasil docking 24 senyawa uji diperoleh tujuh senyawa aktif menghambat reseptor 3B75.pdb dan lima senyawa aktif menghambat reseptor 3O3U.pdb. Kandidat senyawa obat terdiri dari senyawa organosulfur, fenol dan flavonoid. Senyawa $Y$-glutamil-sistein, E-ajoene, N $\alpha$-(1-Deoksi-Dfructosa-1-YL)-L-Arginin, Kaempferol-3-o- $\beta$-D-glukopiranosa, Iso-rhamnetin-3o- $\beta$-D-glukopiranosa merupakan senyawa - senyawa dalam bawang putih yang memiliki kemampuan menghambat baik reseptor 3B75 maupun 303U.

\section{DAFTAR PUSTAKA}

1. Rashid G, Korzets Z, Bernheim J, 2006, Advanced glycation end products stimulate tumor necrosis factor-alpha and interleukin- 1 beta secretion by peritoneal macrophages in patients on continuous ambulatory peritoneal dialysis, Isr Med Assoc J,
8(1):36-9.

2. Sovia E, Jenderal U, Yani A, 2014, Aktivitas inhibisi ekstrak bawang putih dan S-metil sistein terhadap reaksi glikasi albumin secara in vitro, Maranatha Journal of Medicine and Health, $98-109$.

3. Singh R, Morinda citrifolia L, 2012, (Noni): A review of the scientific validation for its nutritional and therapeutic properties, J Diabetes Endocrinol, 3(6):77-91.

4. Neeper M, Marie A, Brett J, Yanq S Du, Pan YE, Elliston K, et al, 1992, Cloning and expression of a cell surface receptor for advanced glycosylation end products of proteins, J Biol Chem, 30 : 14998-5004.

5. Penumutchu SR, Chou R-H, and Yu C, Structural Insights into Calcium-Bound $\mathrm{S} 100 \mathrm{P}$ and the $\mathrm{V}$ Domain of the RAGE Complex, PLoS ONE 2014 ; 9(8): e103947, https://doi,org/10,1371/ journal,pone, 0103947

6. Adrover M, Vilanova B, Frau J, Muñoz F, and Donoso J, 2008, The pyridoxamine action on Amadori compounds: A reexamination of its scavenging capacity and chelating effect, Bioorg Med Chem, 
16:5557-69,

7. Saputri KE, Fakhmi N, Kusumaningtyas E, Priyatama D, Santoso B, 2016, Docking molekular potensi anti diabetes melitus tipe 2 turunan zerumbon sebagai inhibitor aldosa reduktase dengan autodock-vina, Chim Nat Acta, 4(1):16,

8. Purwanggana A, Mumpuni E, Mulatsari E, In vitro and In silico antibacterial activity of 1,5-bis(3'-ethoxy-4'hydroxyphenyl)-1,4-pentadiene-3-one, Int J, Pham Pham Sci $2018 ;(10) 5: 71-6$.

9. Mumpuni E and Mulatsari E, 2018, Molecular Docking and Toxicity Test of Apigenin Derivative Compounds as an Anti-Aging Agent, J Applied Chem, Sci, 5(1): 409-13.

10. Anita Y, Radifar, M, Kardono, L,B, \& Hanafi, M, \& Istyantono, E,P, Structure-based design of eugenol analogs as potential estrogen receptor antagonists, Bioinformation, $2012 ; 8$ (19) : $901-6$.

11. Triana V, 2006, Macam-macam vitamin dan fungsinya dalam tubuh manusia, J Kesehat Masy, 40-7.
12. Korb O, Stützle T, Exner TE, 2006, PLANTS: Application of Ant Colony Optimization to StructureBased Drug Design, Lect notes Comput Sci vol 4150 Ant colony Optim swarm Intell - ANTS2006 Proc, 4150 : 247-58.

13. Purnomo H, 2011, Molecular docking PLANTS (Penambatan molekul PLANTS) (Protein-LigandAnt-System), Yogyakarta: Pustaka Pelajar.

14. Balavignesh V, Srinivasan E, Ramesh Babu NG, Saravanan N, 2013, Molecular docking study on NS5B polymerase of hepatitis $\mathrm{c}$ virus by a screening of volatile compounds from acacia concinna and ADMET prediction, Int J Pharm Life Sci, 4 : 2548 - 58.

15. Kumar KM, Anitha P, Sivasakthi V, Bag S, Lavanya P, Anbarasu A, et al, 2014, In silico study on penicillin derivatives and cephalosporins for upper respiratory tract bacterial pathogens, Biotech, $4: 241-51$.

16. https://www,rcsb,org/3d-view/3B75?preset=ligandIn teraction\&sele $=\mathrm{GLC}$ diakses 3 Juni 2018

17. https://www,rcsb,org/3d-view/3O3U?preset=ligandIn teraction\&sele $=$ MLR diakses 3 Juni 2018 